\title{
Inhibitory Effects of Chaga (Inonotus Obliquus) on Tumor Promotion in Two-Stage Mouse Skin Carcinogenesis
}

\author{
Ayako Akita ${ }^{1}$, Yi Sun ${ }^{1,2}$ and Ken Yasukawa ${ }^{1, *}$ \\ ${ }^{1}$ School of Pharmacy, Nihon University, 7-7-1, Narashinodai, Funabashi, Chiba 274-8555, Japan \\ ${ }^{2}$ Institute of Chinese Materia Medica, China Academy of Chinese Medical Sciences, Beijing, China
}

\begin{abstract}
The methanol extract of chaga (sclerotia of Inonotus obliquus) inhibited the promoting effect of 12-Otetradecanoylphorbol-13-acatate (TPA) applied twice weekly on skin tumor formation in mice initiated with 7,12dimethylbenz [a] anthracene. The methanol extract from chaga led to the isolation of eight triterpenoids (1-8). The antiinflammatory activity of the isolated lanostane-type triterpenes was evaluated against TPA-induced inflammatory ear edema in mice. These compounds showed markedly anti-inflammatory effects, with a 50\% inhibitory dose of $125-458$ nmol/ear.
\end{abstract}

Keywords: Chaga, Inonotus obliquus, lanostane-type triterpene, antitumor promotion, anti-inflammation, two-stage carcinogenesis.

\section{INTRODUCTION}

Our studies have illustrated that components from mushrooms inhibit tumor promotion in mouse skin twostage carcinogenesis [1-6]. In addition, extracts from mushrooms inhibit 12-O-tetradecanoylphorbol-13acetate (TPA)-induced inflammatory ear edema. Active components were thus further isolated from Hypsizigus marmoreus [1], Poria cocos [3], Ganoderma lucidum [5] and Polyporus umbelletus [6].

Since the sixteenth century, the sclerotia of Inonotus obliquus (Hymenochaetaceae), chaga, have been used as a folk medicine for cancer [7]. Recently, it has been reported that chaga contains triterpenoids [8-26] and phenolics [27-29]. On the other hand, we found that lanostane-type triterpenoids inhibit tumor promotion in mouse skin two-stage carcinogenesis [4,5].

Here, we found that methanol extract of chaga (MEC) showed an inhibitory effect on tumor promotion by TPA following initiation with 7,12-dimethylbenz [a] anthracene (DMBA) in mice. In addition, eight triterpenoids were subsequently isolated from MEC.

\section{MATERIALS AND METHODS}

\subsection{General}

Optical rotations were measured with a JASCO P1020 polarimeter. IR spectra were recorded as $\mathrm{KBr}$ pellets on a JASCO FT/IR-300E spectrometer. UV

\footnotetext{
*Address correspondence to this author at the School of Pharmacy, Nihon University, 7-7-1, Narashinodai, Funabashi, Chiba 274-8555, Japan; Tel/Fax: +81474651107; E-mail: yasukawa.ken@nihon-u.ac.jp;

yasukawa.ken@nihon-u.ne.jp
}

spectra were measured on a JASCO V-550 spectrophotometer in absolute $\mathrm{CHCl}_{3}$. HR-EI-MS, EI$M S$ and FAB-MS were measured with a JEOL JMSGCMATE mass spectrometer at an ionization voltage of $70 \mathrm{eV}$. CD spectra were recorded in $\mathrm{CHCl}_{3}$ on a JASCO J-600 spectrometer. ${ }^{1} \mathrm{H}$ and ${ }^{13} \mathrm{C}$ NMR spectra were obtained on a JEOL JNM-LA500 $\left({ }^{1} \mathrm{H}, 500 \mathrm{MHz}\right.$; ${ }^{13} \mathrm{C}, 125 \mathrm{MHz}$ ) spectrometer. $\mathrm{CDCl}_{3}$ was used as the solvent and TMS as the internal standard. Column chromatography was carried out with Sephadex LH-20 (18-111 $\mu \mathrm{m} ; 30 \times 1,000 \mathrm{~mm}$; Amersham Biosciences) and Silica gel 60 (70-230 mesh; $45 \times 220$ mm; Merck). HPLC (Inertsil ODS-EP, $10 \times 250 \mathrm{~mm}$; GL Science Inc.) was run on a JASCO PU-2089 Plus instrument equipped with a JASCO MD-2015 Plus detector and JASCO CO-2060 thermostat.

\subsection{Chemicals}

TPA was purchased from Chemicals for Cancer Research, Inc. (Eden Prairie, MN). DMBA, indomethacin and hydrocortisone were obtained from Sigma Chemical Co. (St. Louis, MO). Acetone, chloroform and methanol were obtained from Tokyo Kasei Kogyo Co., Ltd. (Tokyo, Japan).

\subsection{Material and Extraction}

Chaga, the sclerotia of Inonotus obliquus (Pers.: Fr.) Pil., was obtained from Kinokuniya Kan Yakkyoku Co. (Tokyo, Japan) in 2006. The sample was identified by one of the authors (Yasukawa). The voucher specimen (SM-0603) was deposited in the laboratory of Self Medication at School of Pharmacy, Nihon University (Chiba, Japan). The crushed dry chaga, the sclerotia of $I$. obliquus $(1.0 \mathrm{~kg})$, was extracted three () 2015 Lifescience Global 
times for 3 days each with $\mathrm{MeOH}(5 \mathrm{~L})$ at room temperature to given an extract $(32.4 \mathrm{~g})$. This extract $(30 \mathrm{~g})$ was partitioned between EtOAc- $\mathrm{H}_{2} \mathrm{O}(2.5: 2.5 \mathrm{~L})$. EtOAc extract $(20.6 \mathrm{~g})$ was partitioned between $n$ haxane $(1.9 \mathrm{~L})$ and $\mathrm{MeOH}-\mathrm{H}_{2} \mathrm{O}(1.9: 0.2 \mathrm{~L})$ to obtain $n$ hexane $(9.8 \mathrm{~g})$ and $\mathrm{MeOH}-\mathrm{H}_{2} \mathrm{O}(10.0 \mathrm{~g})$ extracts. The $\mathrm{H}_{2} \mathrm{O}$ layer was partitioned between with $n-\mathrm{BuOH}(2.5 \mathrm{~L})$ to given $n-\mathrm{BuOH}$ extract $(5.5 \mathrm{~g})$ and $\mathrm{H}_{2} \mathrm{O}$ extract $(6.3$ g).

\subsection{Isolation and Identification}

The $\mathrm{MeOH}-\mathrm{H}_{2} \mathrm{O}$ fraction $(10.0 \mathrm{~g})$ was subjected to column chromatography (CC) on Sephadex LH-20 column chromatography $(18-111 \mu \mathrm{m} ; 30 \times 1,000 \mathrm{~mm})$, using $\mathrm{MeOH}-\mathrm{CHCl}_{3}(1: 1)$ to obtain four fractions, fraction 1 (0.65 g; 1-100 mL), 2 (5.2 g; 100-2600 mL), 3 (1.62 g; 2600-3700 mL), 4(1.74 g; 3700-6000 mL).

The inhibitory fraction $2(5 \mathrm{~g})$ was further subjected to CC (silica gel 60, 70-230 mesh; $4.5 \mathrm{~cm} \times 220 \mathrm{~mm}$ ) using $n$-hexane/EtOAc $(4: 1,1.5 \mathrm{~mL} / \mathrm{min})$ to give fraction 2-1 (34.8 $\mathrm{mg} ; 1-130 \mathrm{~mL}$ ), fraction 2-2 (32.6 mg; $130-1150 \mathrm{~mL})$, fraction $2-3(64.7 \mathrm{mg} ; 1150-2300 \mathrm{~mL})$. Elution was continued with $n$-hexane/EtOAc $1: 1$ to give residues fraction $2-4$ (757.5 $\mathrm{mg} ; 1-1140 \mathrm{~mL})$, fraction 25(522.1 mg; 1140-2500 mL) and subsequent column chromatography with $n$-hexane/EtOAc $\quad(1: 3,1.5$ $\mathrm{mL} / \mathrm{min})$ to give residues fraction $2-6(1.1 \mathrm{~g} ; 1-1970$ $\mathrm{mL})$, fraction 2-7(787.6 mg; 1970-6000 mL), respectively.

The active fraction 2-2 was then purified by HPLC (ODS, $85 \% \mathrm{MeOH}, 4.0 \mathrm{~mL} / \mathrm{min}$ ) to give compound 3 (5.2 $\mathrm{mg}, \mathrm{t}_{\mathrm{R}} 29 \mathrm{~min}$ ). Fraction 2-3 was subjected to HPLC (ODS, $82 \% \mathrm{MeOH}, 4.0 \mathrm{~mL} / \mathrm{min}$ ) to give compound 5 (3.4 mg, $\mathrm{t}_{R} 68 \mathrm{~min}$ ). Fraction 2-4 was purified with HPLC (ODS, $74 \% \mathrm{MeOH}, 4.0 \mathrm{~mL} / \mathrm{min}$ ) to give compounds $4\left(242.9 \mathrm{mg}, \mathrm{t}_{R} 72 \mathrm{~min}\right), 5\left(18.0 \mathrm{mg}, \mathrm{t}_{R}\right.$ $85 \mathrm{~min}), 7\left(17.2 \mathrm{mg}, \mathrm{t}_{R} 38 \mathrm{~min}\right)$ and $8\left(32.0 \mathrm{mg}, \mathrm{t}_{R} 53\right.$ min). Fraction 2-5 was separated with HPLC (ODS, $67 \% \mathrm{MeOH}, 4.0 \mathrm{~mL} / \mathrm{min})$ to give compounds $1(10.5$ $\left.\mathrm{mg}, \mathrm{t}_{R} 36 \mathrm{~min}\right), 2\left(8.3 \mathrm{mg}, \mathrm{t}_{R} 155 \mathrm{~min}\right), \mathbf{4}\left(118.6 \mathrm{mg}, \mathrm{t}_{R}\right.$ $164 \mathrm{~min})$ and $6\left(10.6 \mathrm{mg}, \mathrm{t}_{R} 180 \mathrm{~min}\right)$.

Compounds 1-8, the lanostane derivatives methoxyinonotsutriol (1), inotolacton B (2), lanosterol (3), inotodiol (4), 3ß-hydroxylanosta-8, 24-dien-21-al (5), uvariol (6), and $3 \beta$, 22-dihydroxylanosta-7, 9(11), 24-triene (7), and the lupane derivative betulin (8), were elucidated by comparison of spectral data with those in the literature [22-25, 30-32].

\subsection{Animals}

The experiment with mice was performed in accordance with the guidelines of the Institutional Animal Care and Use Committee of Nihon University. Specific pathogen free (SPF) female ICR mice were obtained from Japan SLC Inc. (Shizuoka, Japan). The animals, four per polycarbonate cage, were housed in an air-conditioned SPF room at $24 \pm 2{ }^{\circ} \mathrm{C}, 12$ hour light/dark cycle. Food and water were available $a d$ libitum.

\subsection{TPA-Induced Inflammation Assay in Mice}

For the protocol for this in vivo assay [1-3].

\subsection{Two-Stage Carcinogenesis Experiment}

The back of mice( 7 weeks old) were shaved with electric clippers. Initiation was accomplished by a single topical application of $50 \mu \mathrm{g}$ DMBA. Promotion with $1.0 \mu \mathrm{g}$ TPA, applied twice weekly, was begun 1 week after the initiation. MEC $(1.0 \mathrm{mg})$ or its vehicle, acetone-water-dimethylsulfoxide $(8: 1: 1,100 \mu \mathrm{L})$, was applied topically $30 \mathrm{~min}$ before each TPA treatment. DMBA and TPA were dissolved in acetone, and applied to the shaved area in a volume $100 \mu \mathrm{L}$ using a micropipette. The number and diameter of a skin tumors were measured every other week, and the experiment was continued for 20 weeks. Experimental and appropriate control groups each consisted of 15 mice.

\subsection{Statistical Analysis}

The $50 \%$ inhibitory dose $\left(\mathrm{ID}_{50}\right)$ values and their $95 \%$ confidence intervals $(95 \% \mathrm{Cl})$ were obtained by nonlinear regression using the GraphPad program 5.0 (Intuitive Software for Science, San Diego, CA). Differences between experimental groups were compared by Student's $t$-test and Mann-Whitney $U$ exact test.

\section{RESULTS AND DISCUSSION}

Anti-inflammatory activity may play an important role in the mechanism of antitumor promotion, and several anti-inflammatory substances are known to inhibit the action of tumor promoters. The inhibitory effects of TPA-induced inflammation have been shown to roughly parallel their inhibitory activities against TPAinduced tumor promotion [33]. MEC inhibited TPAinduced inflammation in mice, as shown in Table 1. This suggests that MEC possessed inhibitory effects on inflammation as indicated by the suppression of tumor 
Table 1: Inhibitory Effect of Chaga on TPA-Induced Inflammatory Ear Edema

\begin{tabular}{|c|c|}
\hline Sample & IR \\
\hline $\mathrm{MeOH}$ extract (1 mg/ear) & $84^{* *}$ \\
\hline EtOAc layer ( $1 \mathrm{mg} / \mathrm{ear}$ ) of $\mathrm{MeOH}$ extract & $92^{* *}$ \\
\hline$n$-Hexane layer ( 1 mg/ear) of $\mathrm{MeOH}$ extract & $89^{* *}$ \\
\hline $\mathrm{MeOH}-\mathrm{H}_{2} \mathrm{O}$ layer (1 mg/ear) of $\mathrm{MeOH}$ extract & $94^{* *}$ \\
\hline$n$-BuOH layer (1 mg/ear) of $\mathrm{MeOH}$ extract & 21 \\
\hline $\mathrm{H}_{2} \mathrm{O}$ layer (1 mg/ear) of $\mathrm{MeOH}$ extract & 10 \\
\hline Fraction 1 (0.5 mg/ear) from $\mathrm{MeOH}-\mathrm{H}_{2} \mathrm{O}$ layer of $\mathrm{MeOH}$ extract & $80^{* *}$ \\
\hline Fraction 2 (0.5 mg/ear) from $\mathrm{MeOH}-\mathrm{H}_{2} \mathrm{O}$ layer of $\mathrm{MeOH}$ extract & $87^{* *}$ \\
\hline Fraction 3 (0.5 mg/ear) from $\mathrm{MeOH}-\mathrm{H}_{2} \mathrm{O}$ layer of $\mathrm{MeOH}$ extract & 27 \\
\hline Fraction 4 (0.5 mg/ear) from $\mathrm{MeOH}-\mathrm{H}_{2} \mathrm{O}$ layer of $\mathrm{MeOH}$ extract & $33^{*}$ \\
\hline
\end{tabular}

Note: IR: Inhibitory ratio at $1 \mathrm{mg} / \mathrm{ear} .{ }^{*} P<0.05 ;{ }^{*} P<0.01$ by one-way ANOVA compared with the control group.
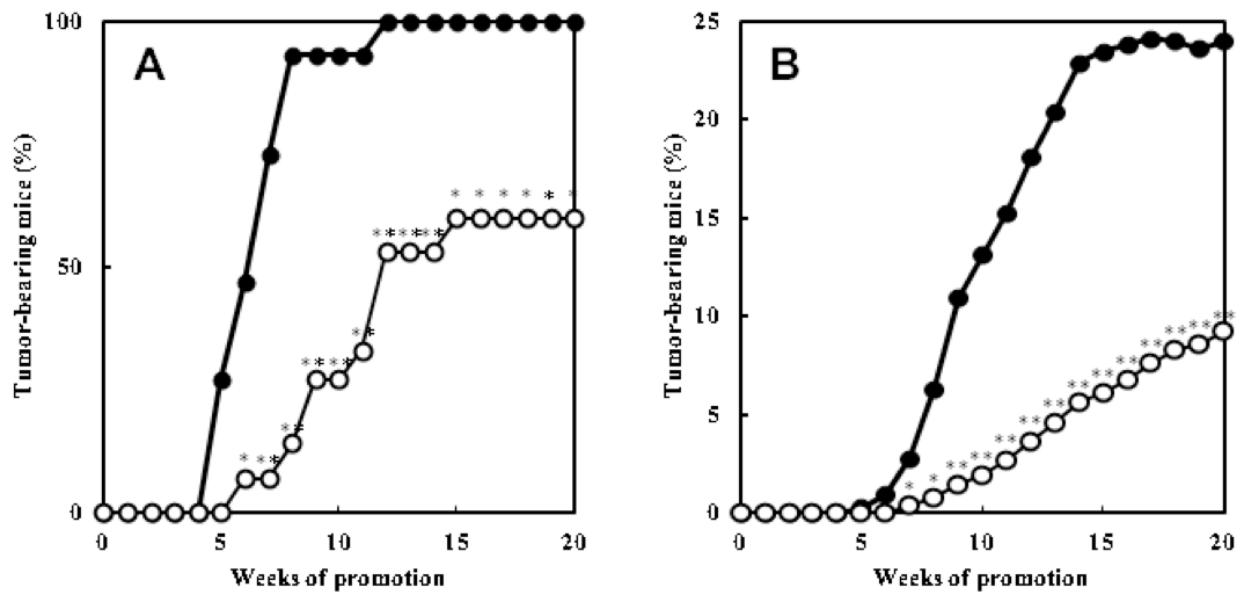

Figure 1: Inhibitory effect of $\mathrm{MeOH}$ extract of chaga on tumor promotion of skin papillomas by TPA in DMBA-initiated mice.

From 1 week after initiation with a single topical application of $50 \mu \mathrm{g}$ of DMBA, $1 \mu \mathrm{g}$ of TPA was applied twice weekly. Topical application of the $\mathrm{MeOH}$ extract $(1 \mathrm{mg})$ and vehicle was performed 30 min before each TPA treatment. Data are expressed as the percentage of mice bearing papillomas $(\mathbf{A})$, and as the average number of papillomas per mouse (B). $\bullet,+$ TPA with vehicle alone; $\circ$, +TPA with $\mathrm{MeOH}$ extract of chaga. The treated group was determined to be statistically different from the control group by Mann-Whitney $U$ exact test $(\mathbf{A})$ and by Student's $t$-test $(\mathbf{B}) .{ }^{*} P<0.05$ and ${ }^{* *} P<0.01$.

promotion in mouse skin. We further determined the effects of MEC on chronic inflammatory diseases using a two-stage carcinogenesis in mouse skin.

The activities, evaluated by both the rate (\%) of pappilloma-bearing mice and the average number of papillomas per mouse were compared with those of a positive control. As shown in Figure 1, on the positive control, $100 \%$ of mice bore pappilomas at week 12 of promotion, and 23.7 pappilomas were formed per mouse after 20 weeks of promotion. When EMC were applied before TPA treatment, the delayed the formation of pappilomas as follows. In the group treated with EMC, only $60 \%$ of the mice bore pappilomas, even at 20 weeks of promotion (Figure 1A). Also, EMC reduced the number of pappilomas per mouse as follows. In the case of EMC, 9.3 pappillomas were formed per mouse after 20 weeks of promotion. EMC exhibited $61 \%$ inhibition at week 20 , as shown Figure 1B. There were no differences regarding body weight between the control and treated group during experiment (data not shown).

MEC was purified by column chromatography on Sephadex LH-20 and silica gel followed by preparative reverse phase HPLC, yielding seven known lanostane derivatives, methoxyinonotsutriol (1), inotolacton B (2), lanosterol (3), inotodiol (4), 3ß-hydroxylanosta-8, 24dien-21-al (5), uvariol (6) and $3 \beta$, 22-dihydroxylanosta7, 9(11), 24-triene (7), and the lupane derivative betulin 
(8). Active components were then isolated from MEC (Figure 2). The structures of these compounds were elucidated by their spectroscopic data with those reported in the literature. These compounds showed inhibitory activity against TPA-induced ear edema. The $I D_{50}$ values for 1-8 on TPA-induced inflammation were between 125-458 nmol/ear, as shown in Table 2. In comparison with standard drugs, these triterpenoids had higher activity than indomethacin $\left(\mathrm{ID}_{50}\right.$ : 908 nmol/ear), an anti-inflammatory drug.

The inhibitory effects against TPA-induced inflammation have been demonstrated to closely parallel those of the inhibition of tumor promotion in two-stage carcinogenesis initiated by DMBA and TPA, a well-known tumor promoter, in a mouse skin model
[33]. In our study, we found that topical application of MEC postponed the period of $50 \%$ of papilloma bearers and all isolated compounds from MEC exhibited potent anti-inflammatory effects on in vivo assay. Chaga triterpenes may be found to inhibit inflammation and tumor promotion in mouse skin. In addition, the triterpenes of chaga showed intermediate inhibitory effects when compared with the triterpenes of Poria cocos [3] and Ganoderma lucidum [5]. Lanostane-type triterpenes from Poria cocos inhibited pospholipase $A_{2}$ [34], which is related to inflammation, and these lanostane-type triterpenoids (1-7) may suppress the same enzyme. Many triterpenes, widely distributed in edible mushrooms and plants, are now known to inhibit the tumor promoting activities of TPA in mice and this suggests that they may be important<smiles>COC1CC2C(C)(C)[C@@H](O)CC[C@]2(C)C2=C1[C@@]1(C)CC[C@H]([C@H](O)CC=C(C)C)[C@]1(C)C[C@H]2O</smiles>

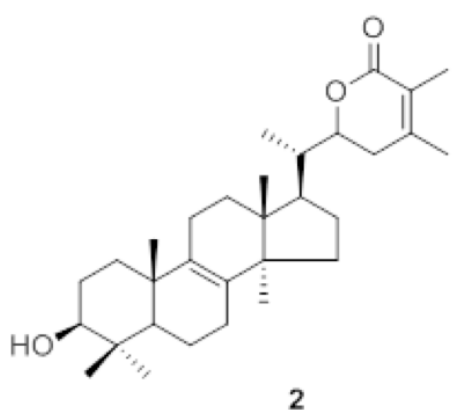

2

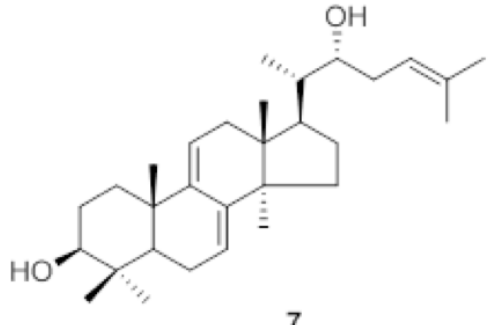

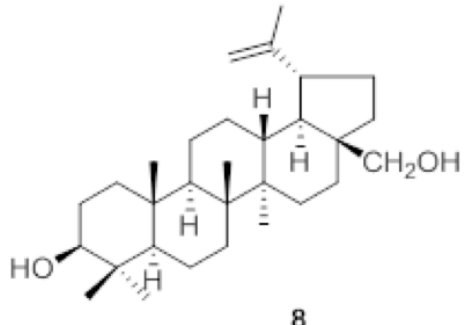

8

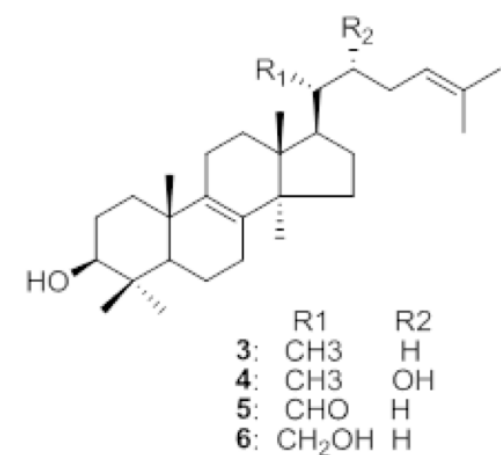

Figure 2: Chemical structures of compounds 1-8 from chaga.

Table 2: Inhibitory Effect of Triterpenoids from Chaga on TPA-Induced Inflammatory Ear Edema

\begin{tabular}{|c|c|c|}
\hline Compound & ID50 (nmol/ear) & 95\% Cl (nmol/ear) \\
\hline \hline Methoxyinonotsutriol (1) & 272 & $227-353$ \\
\hline Inotolacton B (2) & 265 & $416-503$ \\
\hline Lanosterol (3) & 458 & $103-152$ \\
\hline Inotodiol (4) & 125 & $310-448$ \\
\hline 33-Hydroxylanosta-8, 24-dien-21-al (5) & 389 & $98-184$ \\
\hline Uvariol (6) & 134 & $256-439$ \\
\hline 3ß,22-Dihydroxylanosta-7,9(11),24-triene (7) & 335 & $408-495$ \\
\hline Betulin (8) & 448 & $755-1092$ \\
\hline Indomethacina & 908 & \\
\hline
\end{tabular}

Note: ${ }^{a}$ Reference compounds. ID50: 50\% Inhibitory dose. 95\% Cl: 95\% Confidence intervals. 
dietary additives for the chemoprevention of cancer. This is the first report to find that MEC inhibits TPAinduced inflammatory ear edema in mice. Furthermore, MEC inhibits tumor promotion by TPA following initiation with DMBA in mice. In addition, the bioactive elucidation of chaga at the molecular level is necessary.

\section{CONFLICTS OF INTEREST}

There are no potential conflicts of interest to disclose.

\section{FINANCIAL DISCLOSURE}

\section{Grant Support}

This work was supported, in a part, by "High-Tech Research Center" Project for Private Universities: matching fund subsidy from MEXT (Ministry of Education, Culture, Sports, Science and Technology), 2007-2012, of Japan.

\section{ACKNOWLEDGEMENTS}

We would also like to thank Dr. Kouichi Metori (Analytical Center, College of Pharmacy, Nihon University) for assistance with mass spectroscopy.

\section{ABBREVIATIONS}

$$
\begin{aligned}
& 95 \% \mathrm{Cl}=95 \% \text { Confidence intervals } \\
& \text { DMBA }=7,12-\text { Dimethylbenz[a] anthracene } \\
& \mathrm{EMC}=\text { Methanol extract of chaga } \\
& \mathrm{ID}_{50}=50 \% \text { Inhibitory dose } \\
& \mathrm{MeOH}=\text { Methanol } \\
& \mathrm{TPA}=12-\mathrm{O} \text {-Tetradecanoylphorbol-13-acetate }
\end{aligned}
$$

\section{REFERENCES}

[1] Yasukawa K, Aoki T, Takido M, et al. Inhibitory effects of ergosterol isolated from the edible mushroom Hypsizigus marmoreus on TPA-induced inflammatory ear oedema and tumour promotion in mice. Phytother Res 1994; 8: 10-3. http://dx.doi.org/10.1002/ptr.2650080103

Yasukawa K, Kanno H, Kaminaga T, et al. Inhibitory effect of methanol extracts from edible mushroom on TPA-induced ear oedema and tumour promotion in mouse skin. Phytother Res 1996; 10: 3679

http://dx.doi.org/10.1002/(SICI)1099-

1573(199606)10:4<367::AID-PTR852>3.0.CO;2-D

[3] Kaminaga T, Yasukawa K, Takido M, Tai T, Nunoura Y. Inhibitory effect of Poria cocos on 12-Otetradecanoylphorbol-13-acetate-induced ear oedema and tumour promotion in mouse skin. Phytother Res 1996; 10: 581-4.

http://dx.doi.org/10.1002/(SICI)10991573(199611)10:7<581::AID-PTR907>3.0.CO;2-3
[4]

Kaminaga $\mathrm{T}$, Yasukawa $\mathrm{K}$, Kanno $\mathrm{H}$, et al, Inhibitory effects of lanostane-type triterpene acids, the components of Poria cocos, on tumor promotion by 12-O-tetradacanoylphorbol-13acetate in two-stage carcinogenesis in mouse skin. Oncology 1996; 53: 382-5.

http://dx.doi.org/10.1159/000227592

[5] Akihisa $T$, Nakamura $\mathrm{Y}$, Tagata $\mathrm{M}$, et al, Anti-inflammatory and anti-tumor-promoting effects of triterpene acids and sterols from the fungus Ganoderma lucidum. Chem Biodiv 2007; 4: 224-31.

http://dx.doi.org/10.1002/cbdv.200790027

[6] Sun Y, Yasukawa K. New anti-inflammatory ergostane-type ecdysteroids from the sclerotium of Polyporus umbellatus. Bioorg Med Chem Lett 2008; 18: 3417-20. http://dx.doi.org/10.1016/j.bmcl.2008.04.008

[7] Saar M. Fungi in khanty folk medicine. J Ethnopharmaco 1991; 31: 175-9. http://dx.doi.org/10.1016/0378-8741(91)90003-V

[8] Kahlos K, Hiltunen R. Identification of some lanostane type triterpenes from Inonotus obliquus. Acta Pharm Fennica 1983; 92: 220.

[9] Kahlos K, Hiltunen R, Schantz M. v. 3ß-Hydroxy-lanosta8,24-dien-21-al, a new triterpene from Inonotus obliquus. Planta Med 1984; 50: 197-8. http://dx.doi.org/10.1055/s-2007-969674

[10] Kahlos K, Hiltunen R. Sterols and triterpene in Inonotus obliquus. Acta Agronomica 1985; 34: 82.

[11] Kahlos K, Tuulikki S, Hiltunen R. The occurrence of some sterols and triterpenes in Inonotus radiatus. Acta Pharm Fennica 1985; 98: 33-7.

[12] Kahlos K, Hiltunen R. Two new oxygenated lanostane type triterpenes from Inonotus obliquus. Acta Pharm Fennica 1986; 95: 71-6.

[13] Kahlos K. 3ß, 22-Dihydroxy-lanosta-8,24-dien-7-one, a new 7-keto compound from Inonotus obliquus. Acta Pharm Fennica 1986; 95: 113-7.

[14] Kahlos K, Hiltunen R. 3ß,22-Dihydroxy-lanosta-7,9(11),24triene, a new minor compound from Inonotus obliquus. Planta Med 1986; 52: 495-6. http://dx.doi.org/10.1055/s-2007-969266

[15] Kahlos K, Kangas L, Hiltunen R. Antitumor activity of some compounds and fractions from an $n$-hexane extract of Inonotus obliquus. Acta Pharm Fennica 1987; 33-40.

[16] Shin Y, Tamai Y, Terazawa M. Chemical Constituents of Inonotus obliquus I. A new triterpene, 3 $\beta$-hydroxy-8, 24-dienlanosta-21, 23-lactone from sclerotum. Eurasian J For Res 2000; 1: 43-50. http://eprints.lib.hokudai.ac.jp/dspace/ bitstream/2115/22123/1/1_P43-50.pdf

[17] Shin Y, Tamai Y, Terazawa M. Chemical constituents of Inonotus obliquus II: a new triterpene, 21, 24cyclopentalanosta-3, 21, 25-triol-8-ene from sclerotium. J Wood Sci 2001; 47: 313-6. http://dx.doi.org/10.1007/BF00766719

[18] Shin Y, Tamai Y, Terazawa M. Chemical Constituents of Inonotus obliquus (Pers.:Fr.) Pil. (Aphyllophoromycetideae) III: a new triterpene, 3 $\beta, 22$, 25-trihydroxy-lanosta-8-ene from sclerotia. Int J Med Mushroom 2000; 2: 201-7. http://dx.doi.org/10.1615/IntJMedMushr.v2.i3.30

[19] Shin Y, Tamai Y, Terazawa M. Chemical Constituents of Inonotus obliquus IV. Triterpene and steroids from cultured mycelia. Eurasian J For Res 2001; 2: 27-30. http://eprints.lib.hokudai.ac.jp/dspace/bitstream/2115/22127/ 1/2_P27-30.pdf

[20] He J, Feng X-Z, Zhao B, Lu Y. Triterpenoids from Fuscoporia obliqua. Chin Chem Lett 2000; 11: 45-8. http://www.mushroomhunter.net/chaga\%20pdf/fuscoporia\%20triterpenoids.pdf

[21] Taji S, Yamada T, In Y, et al, Three new lanostane triterpenoids from Inonotus obliquus. Helv Chim Acta 2007; 90: 2047-57.

http://dx.doi.org/10.1002/hlca.200790214 
[22] Taji S, Yamada $\mathrm{T}$, Tanaka $\mathrm{R}$. Three new lanostane triterpenoids, inonotsutriols $\mathrm{A}, \mathrm{B}$, and $\mathrm{C}$, from Inonotus obliquus. Helv Chim Acta 2008; 91: 1513-24. http://dx.doi.org/10.1002/hlca.200890165

[23] Nakata T, Yamada T, Taji S, et al, Structure determination of inonotsuoxides $\mathrm{A}$ and $\mathrm{B}$ and in vivo anti-tumor promoting activity of inotodiol from the sclerotia of Inonotus obliquus. Bioorg Med Chem 2007; 15: 257-64. http://dx.doi.org/10.1016/j.bmc.2006.09.064

[24] Taji S, Yamada T, Wada S, et al, Lanostane-type triterpenoids from the sclerotia of Inonotus obliquus possessing anti-tumor promoting activity. Eur $\mathrm{J}$ Med Chem 2008; 43: 2373-9. http://dx.doi.org/10.1016/j.ejmech.2008.01.037

[25] Nakamura S, Iwami J, Matsuda H, Mizuno S, Yoshikawa M. Absolute stereostructures of inoterpenes A-F from sclerotia of Inonotus obliquus. Tetrahydron 2009; 65: 2443-50. http://dx.doi.org/10.1016/j.tet.2009.01.076

[26] Handa N, Yamada T, Tanaka R. An unusual lanostane-type triterpenoid, spiroinonotsuoxodiol, and other triterpenoids from Inonotus obliquus. Phytochemistry 2010; 71: 1774-9. http://dx.doi.org/10.1016/j.phytochem.2010.07.005

[27] Nakajima Y, Sato Y, Konishi T. Antioxidant small phenolic ingredients in Inonotus obliquus (person) Pilat (Chaga). Chem Pharm Bull (Tokyo) 2007; 55: 1222-6. http://dx.doi.org/10.1248/cpb.55.1222

[28] Lee I-K, Kim Y-S, Jang Y-W, Jung J-Y, Yun B-S. New antioxidant polyphenols from the medicinal mushroom
Inonotus obliquus. Bioorg Med Chem Lett 2007; 17: 6678-81.

http://dx.doi.org/10.1016/j.bmcl.2007.10.072

[29] Nakajima $Y$, Nishida H, Nakamura $Y$, Konishi T. Prevention of hydrogen peroxide-induced oxidative stress in PC12 cells by 3,4-dihydroxybenzalactone isolated from Chaga (Inonotus obliquus (person) Pilat). Free Radical Biol Med 2009; 47: 1154-62.

http://dx.doi.org/10.1016/j.freeradbiomed.2009.07.029

[30] Tinto WF, Blair LC, Alli A. Lupane triterpenoids of Salacia cordata. J Nat Prod 1992; 55: 395-8. http://dx.doi.org/10.1021/np50081a020

[31] Handa N, Yamada T, Tanaka R. Four new lanostane-type triterpenoids from Inonotus obliquus. Phytochemistry Lett 2012; 5: 480-5. http://dx.doi.org/10.1016/i.phytol.2012.04.010

[32] Ying Y-M, Zhang L-Y, Zhang $X$, et al, Terpenoids with alphaglucosidase inhibitory activity from the submerged culture of Inonotus obliquus. Phytochemistry 2014; 108: 171-6. http://dx.doi.org/10.1016/j.phytochem.2014.09.022

[33] Yasukawa K, Takido M, Takeuchi M, Nakagawa S. Effect of chemical constituents from plants on 12-O tetradecanoylphorbol-13-acetate-induced inflammation in mice. Chem Pharm Bull (Tokyo) 1989; 37: 1071-3. http://dx.doi.org/10.1248/cpb.37.1071

[34] Cuéllar MJ, Giner RM, Recio MC, et al. Two fungal lanostane derivatives as phospholipase $A_{2}$ inhibitors. J Nat Prod 1996; 59: 977-9. http://dx.doi.org/10.1021/np9604339 